\title{
Decision-Making in Planning International Freight Transport
}

\author{
Dariusz Masłowski, Małgorzata Dendera-Gruszka, Ewa Kulińska \\ And Joanna Rut \\ Opole University of Technology, Faculty of Production Engineering \\ and Logistics, Opole, Poland \\ Correspondence should be addressed to: Dariusz Masłowski; d.maslowski@po.edu.pl
}

Received date: 10 March 2020; Accepted date :16 July 2020; Published date: 8 September 2020

Academic Editor: Katarzyna Liczmańska-Kopcewicz

Copyright (c) 2020. Dariusz Masłowski, Małgorzata Dendera-Gruszka, Ewa Kulińska And Joanna Rut. Distributed under Creative Commons Attribution 4.0 International CC-BY 4.0

\begin{abstract}
The planning of international freight transport is one of the most important tasks carried out in transport companies. The aim of this publication is to improve the process of planning international transport by creating a generalized model presented on an example in Europe and a decision-making model developed for it. In the field of research methods, the methods of observation of transport service providers and analysis of existing data were used. As a result of the work, a generalised model of the freight planning process was developed and the optimal solution for the choice of transport option was presented. From the developed decision-making model, it can be concluded that if transport is made by land and sea using hired means of transport, it should be eliminated. The optimal result of the decision analysis may be that if the transport takes place using an external forwarding company, the choice of the transport process and the determination of the type of transport remains unknown. Thanks to the applications contained in the article, both transport companies and manufacturing companies can make a decision on the choice of international freight transport services in a simple and transparent way.
\end{abstract}

Keywords: Decision-Making Model of Transport Process, International Transport, Forwarding, Planning Process

Cite this Article as: Dariusz Masłowski, Małgorzata Dendera-Gruszka, Ewa Kulińska And Joanna Rut (2020), "Decision-Making in Planning International Freight Transport" Journal of Supply Chain and Customer Relationship Management, Vol. 2020 (2020), Article ID 981734, DOI: 10.5171/2020.981734 


\section{Introduction}

Transport process planning is one of the most important tasks carried out in transport companies. Proper organization and planning guarantees that the company can achieve its goals, such as: profit or further development. Proper planning of transport processes is to serve primarily to minimize the mistakes made. This will result in lower costs incurred by forwarding companies and increased customer satisfaction.

When planning transport processes, it is important to remember that all accepted orders should be fulfilled. At the same time, an important issue during the realization of transport processes is to minimize the costs arising during the process. Enterprises are looking for experts who deal with rational transport planning. According to Ding (2020), the idea is to combine at the same time the expectations of customers, which are: speed, price competitiveness, safety of transported goods, with the goals of transport companies that strive to maximize profits.

According to Masłowski et al. (2019), important factors to be taken into account when organising transport processes include:

- proper selection of a vehicle and a driver for a given transport task, - determining the best route for the carriage of goods or passengers from point A to point $B$.

Such problems can be easily eliminated if you have the appropriate technical facilities, in the form of one or two vehicles, with multiple orders during the week. The situation becomes more complicated if the company has just entered the market and does not have a large technical background. Then good route planning is a priority, but it becomes complicated and time consuming.

The aim of this publication is to improve the transport process by creating a generalized model for planning the transport of goods in Europe, together with a pre-determined decision-making model for the problem under investigation. An example of the process of planning the transport of dangerous goods from Opole to Stockholm is presented. To verify the objective, theoretical research tools were used, such as analysis, synthesis, generalisation and comparison. In terms of practical methods, observation methods of companies providing transport services were used.

Realization of each transport process of hazardous material implies a certain risk of an unwanted (accident) event, caused by scattering (effusion, shedding, etc.) of burden, with the consequences related to the nature of the hazardous material that is being transported. By mentioning all of these risks, the transport safety is a very important and responsible task. In the case of an accident, the consequences can be very large and can cause damage to people and their environment, namely, death, diseases of human beings, plant and animals, pollution of environment, destruction of natural and national resources, damage of industrial buildings, traffic communications and their respective facilities. Potential danger, on one hand, and the need for transport of hazardous materials, on the other hand, both lead to the necessity of setting specific requirements related to risk reduction and attempts to increase the safety in the transport of hazardous materials. With the growth of ecological consciousness, there is also a growing demand for reduction of transport risks, but also in handling, in general, hazardous materials. According to Noureddine et al. (2019), for these reasons, many countries, institutions and organisations have different regulations and other regulatory measures in place to manage the safety of these transport processes. 


\section{The essence of the transport process}

Almost all aspects of early preparation are taken into account when planning a transport. The most important factors influencing the organisation of the transport process are: drivers' working time, costs of transport charges, loading and unloading dates, determination of the maximum time for transporting cargo.

The transport planning process is related to forwarding, which organizes the cargo movement for profit as a substitute for the principal and performs related activities, except for the physical transport itself (Marzec, 1996). The article presents the basic forwarding activity, i.e. planning and organization of physical transport process.

\section{The Transport Process}

Transport is an activity consisting in the provision of services against payment. It involves the movement of people and/or cargo from the starting point to the ending point and the enrichment of activities with auxiliary services closely related to transport (Rydzkowski, Wojewódzka-Król, 2007). However, each industry has its own specificity. In transport, factors such as punctuality, quality, reliability, confidentiality and brand are of paramount importance. Gaining the trust of a new customer is often a difficult and timeconsuming process (Wojtynek, et al., 2016). The transport process, on the other hand, according to the Polish standard no. 72 , is a series of interrelated transport operations, performed in a fixed order on a given route and at a given time (PN - 72/ M - 78000). Therefore, it is necessary to consider which operations during the planning of the transport process are most important for the effective transport of goods or services. The following activities can be distinguished in the transport process: organizational, executive, and commercial.

Activities in the transport process are responsible for various aspects of transport organisation. Examples of organizational activities can be planning routes or preparing proper transport documentation. The executive activities may include activities directly related to physical transport. They are key elements of the transport process. The process also lists the commercial activities that regulate the charges for transport services (Stajniak, et al. 2007).

In practice, the transport process includes the following phases (Kulińska, Masłowski, Wojtynek, 2018):

- preparation of the transport concept, - preparing the cargo for transport, - the organization of the transport process, - physical movement of the cargo, - handling commercial activities, - analysis and evaluation of the completed process (costs, time, quality, complaints).

They condition the transport process and its efficiency. The article presents in detail the first phase, i.e. preparation of the transport concept.

\section{International Transport}

International road transport in general, as well as in accordance with Article 4, point (a), (b), (c) and (d). 2 of the Road Transport Act of 6 September 2001 is understood as transporting cargo beyond the borders of one country (Dz.U. 2001 Nr 125 poz. 1371).

In transnational corporations, building an international supply chain is important to achieving the organization's goals. One of the main reasons for building international supply chains is for companies to reduce costs. It concerns both the costs of transport, servicing of logistics centers and transaction costs (Izdebski, et al. 2019). In addition, they allow you to reduce the time of transport and storage of materials, goods and semi-finished products and reduce inventory.

The transport of dangerous goods concerns many economic sectors, as materials and objects meeting these criteria are present in almost every industry. Dangerous goods are not only used as raw materials in the production process, but are also used in other areas, e.g. to assist in conducting 
analytical tests or as means of keeping machines and equipment in the production line clean (van Heeswijk, Mes, Schutten, 2019). Dangerous goods must be transported in accordance with the requirements set out in the relevant regulations before they can be placed in the company. Meeting the guidelines in this area guarantees safe transport, which ensures protection of human health and life, protection of the environment and property by eliminating the risk of accident, incident or emergency. Transport of dangerous goods is carried out by road, rail, air, inland waterway and sea (Noureddine, Ristic, 2019).

A prerequisite for the admission of dangerous goods for transport is to comply with ADR regulations, laws, procedures, preparations and the provision of appropriate technical resources. In the transport system, an object or substance having the characteristics of a dangerous good must be identified, classified and named with a unique and standard name, used in ADR regulations. Dangerous goods are classified by comparing their physicochemical and biological properties with the classification criteria specified in the ADR agreement. In case when a good may pose more than one hazard, allocation to a given class is made on the basis of the "dominant hazard" criterion. (Akhmedov, et al., 2019)

When planning the route for a vehicle on which hazardous materials will be placed, particular attention should be paid to roads with the best possible surface and low traffic. Due to the potential threat to the environment as well as human health and life, roads running near active leisure centers as well as sports or built-up areas of the city should be excluded (van Heeswijk, Mes, Schutten, 2019).

In the management of international transport, it is important to follow the regulations in force in the given country. However, an important factor in their implementation is the appropriate integration of many aspects such as: time, cost, transport capability (Romanova, et.al., 2019). Therefore, regardless of whether it is the transport of dangerous goods or other types of goods, the transport process should take place on the main decisionmaking principles, constituting problems in the provision of services.

\section{Generalized Transport Process Model}

In practice, the transport process creates serious obstacles for planners in companies due to its complexity and the lack of structured activities. Figure 1 shows a generalized model of the transport process presented as a block diagram. Common activities not dependent on the modes of transport are marked in red, activities related to rail transport are marked in orange, activities related to sea transport are marked in yellow and road transport is marked in green. The external mode of transport is marked in violet, and decision-making activities are marked in grey. 


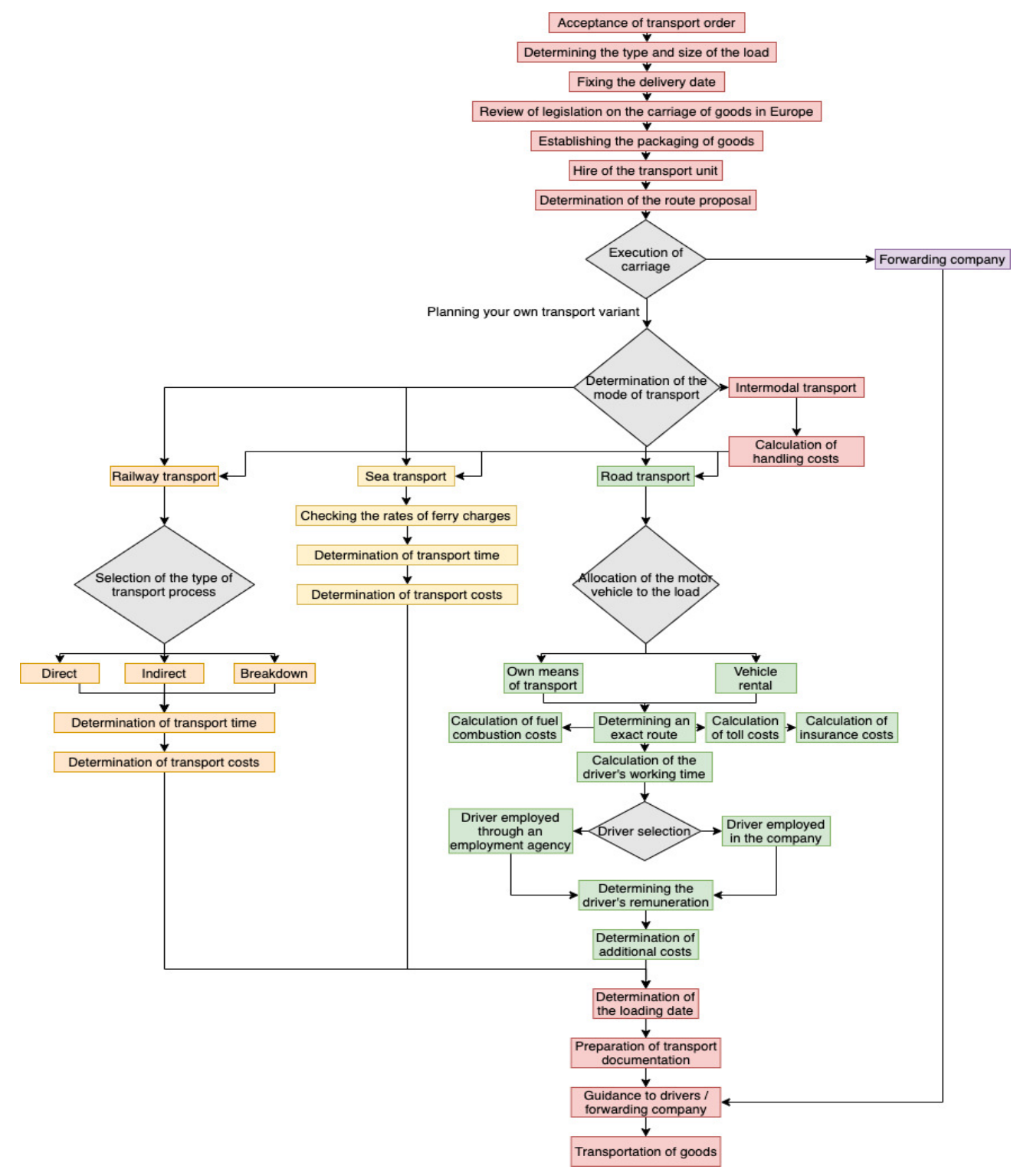

Fig. 1: Generalized transport process model [own study]

Thanks to its construction, the transport planners in companies can easily read out the activities that follow in order to complete a transport order. Unfortunately, the whole transport process is much more complicated and intricate, so it cannot be fully systematized and modelled. The proposed model does not take into account, for example, such issues as document flow, time of execution of individual tasks, or some important assumptions when planning transport by other means of transport than road transport.

\section{Decision boards}

Decision boards are used to document and analyze the system, which are complementary to the classic schemes of modification and solution search. The basis for the construction of decision boards is the condition: "If ..., then ...", which is why 
they allow the construction of automatic information processing diagrams. Decision boards consist of a set of rules that are designed to describe what set of conditions must be met in order for the proper scope of activities to be undertaken (Partyka, 2001, Paszek, Partyka, 2014). Table 1 presents a standard decision-making table.

Table 1: Example of a decision table [own study based on Partyka, 2001]

\begin{tabular}{|l|l|l|}
\hline \multicolumn{2}{|l|}{ Name of the table } & $\begin{array}{l}\text { Rules of decision } \\
\mathbf{R}_{1}, \mathbf{R}_{2}, \ldots \mathbf{R}_{\mathbf{n}}\end{array}$ \\
\hline & $\mathrm{W}_{1}$ & \\
Set of conditions & $\mathrm{W}_{2}$ & Set of conditionality indicators \\
& $\ldots$ & \\
\hline & $\mathrm{W}_{\mathrm{n}}$ & \\
\hline \multirow{3}{*}{ Set of activities } & $\mathrm{C}_{1}$ & \\
& $\mathrm{C}_{2}$ & Set of activity indicators \\
& $\ldots$ & \\
\hline
\end{tabular}

The set of conditions defines the expressions "If...", which define the variables that have the greatest impact on the decision-making system. The set of actions describes the expressions "to...", which contain all possible actions. The set of condition indicators is based on the symbols Y (Yes), N (No) and "-". (nothing) that specify whether or not a given condition is met or whether or not it influences decisions. A set of activity indicators is described in the same way as a set of condition indicators.

\section{Sample Cargo Transport Plan}

This chapter presents a sample plan for the transport of $220 \mathrm{~m}^{3}$ of dangerous goods (ADR) from Opole to Stockholm. The transport process has been created on the basis of the generalized model proposed in the article.

The provisions of the Act on the Transport of Dangerous Goods of 19 August 2011 and the restructured European Agreement on ADR impose an obligation on an entrepreneur who performs road transport of dangerous goods or loading or unloading related to such transport to appoint, at his own expense, a safety advisor for the transport of dangerous goods (www.doradca-adr.pl/...).

After analysing the possibilities, the following types of transport were identified:

- road-sea transport with hired means of transport

- road-maritime-rail transport

Road-sea transport with hired means of transport

The route was planned in 3 different variants:

- Option 1 contains 3 transport stages: the total length of the route: $1507 \mathrm{~km}$ - Stage 1: Opole (PL) - Rostock (DE) - $657 \mathrm{~km} \mathrm{-} \mathrm{land} \mathrm{road}$ - Stage 2: Rostock (DE) - Gedser (DK) - $49 \quad \mathrm{~km} \quad$ - seaway - Stage 3: Gedser (DK) - Stockholm (SE) - $801 \mathrm{~km} \mathrm{-} \mathrm{overland} \mathrm{road}$

- Option 2 contains 3 transport stages: total length of the route: $1129 \mathrm{~km}$ - Stage 1: Opole (PL) - Gdansk (PL)

- $542 \mathrm{~km} \mathrm{-} \mathrm{land} \mathrm{road}$ - Stage 2: Gdansk (PL) Nynäshamn (SE) - 529 km - seaway 
- Stage 3: Nynäshamn (SE)Stockholm (SE) - $58 \mathrm{~km}$ - land road

- Option 3 contains 3 transport stages: total length of the route: $1819 \mathrm{~km}$ - Stage 1: Opole (PL) Frederikshavn (DK) - $1252 \mathrm{~km}$ - land road - Stage 2: Frederikshavn (DK) Gothenburg (SE) - $90 \mathrm{~km}$ - seaway - Stage 3: Gothenburg (SE) Stockholm (SE) - $477 \mathrm{~km} \mathrm{-} \mathrm{land} \mathrm{road}$

Fixed costs for road and sea transport:

- fuel (ON) as of 9.12.2019 (www.epetrol.pl/notowania): Poland - 4.96 PLN/l, Germany - 5,46 PLN/l, Denmark - 6.31 PLN/l, Sweden - 6.17 PLN/l. The average of 5.73 PLN/l was used for calculations, - the driver's salary (www.pracuj.pl/praca/...,

www.postawnaswoim.pl/kariera/...): 341 PLN for a driver in individual transport and 295 PLN/day for one driver in two-person transport,

- renting a means of transport (www.automilan.pl/...): tractor - 6000 PLN net/month (burning 25 l/100km empty, with load +0.3 l), tank - 7000 PLN net/month (gross capacity 3820036200 net), for loading $220 \mathrm{~m}^{3} 6$ road sets are needed, where the cost of driving with an empty tank is $127.5 \mathrm{PLN} / 100 \mathrm{~km}$, while the cost of driving with a loaded tank is 180 PLN/100 km, - ferry crossing (www.aferry.pl... , www.freightlink.pl...): Rostock-Gedser, Gedser-Rostock: 3475.6 PLN, GdańskNynäshamn: 1 driver - EUR 928.75, 2 drivers: 1046,35 EUR, Nynäshamn Gdansk: 1 driver: 661,48 EUR, 2 drivers: 1 driver: 661,48 EUR: 779,09 EUR, Frederikshavn - Gothenburg: 1 driver: 1914,6 PLN, 2 drivers: 2115.8 PLN, - road tolls (www.viatoll.pl...): Opole Olszyna: 60.75 PLN, Opole - Gdańsk: 70.99 PLN,

- cleaning of the tank (www.b10.com.pl/wash-price.html...): 1 set - 440 PLN, 6 sets - 2640 PLN.

Calculation of the cost of the road driven:

- variant 1: Opole - Stockholm: stage 1: 657 $\mathrm{km}$ - cost $1182.6 \mathrm{zł}$, stage 2 : ferry trip, stage
3: $801 \mathrm{~km} \mathrm{-} \mathrm{cost} 1441.8 \mathrm{zł}$, Stockholm Opole: stage 1: $801 \mathrm{~km}$ - cost $1021.28 \mathrm{zł}$, stage 2: ferry trip, stage 3: $657 \mathrm{~km}$ - cost 837.68

zł, - variant 2: Opole - Stockholm: stage 1: 542 $\mathrm{km}$ - cost PLN 975.6, stage 2: ferry trip, stage 3: $58 \mathrm{~km}$ - cost PLN 104.4, Stockholm - Opole: stage 1: $58 \mathrm{~km}$ - cost PLN 73.95, stage 2: ferry trip, stage 3: $542 \mathrm{~km}$ - cost PLN 681.29, - variant 3: Opole - Stockholm: stage 1: $1252 \mathrm{~km}$ - cost PLN 2253.6, stage 2 - ferry trip, stage 3 - $477 \mathrm{~km}$ - cost PLN 858.6, Stockholm - Opole: stage 1: $477 \mathrm{~km}$ - cost PLN 608.18, stage 2 - ferry trip, stage 3: $1252 \mathrm{~km}$ - cost PLN 1596.3.

Working time of drivers:

variant 1: for 1 driver: departure on Monday at 00:00, return on Thursday at 7:43. The transport time is: $3 \mathrm{~d} 7 \mathrm{~h} 43 \mathrm{~min}$, for 2 drivers: departure on Monday at 04:00, return on Thursday at 15:43. The transportation time is as follows: $2 \mathrm{~d} 11 \mathrm{~h}$ 43

$\min$, variant 2: for 1 driver: departure at 09:00 on Monday, return at 7:32 on Thursday, for 2 drivers: departure at 10:00 on Monday, return at 10:32 on Wednesday, variant 3: for 1 driver: departure at 08:00 on Monday, return at 15:45 on Friday, for 2 drivers: departure at 20:00 on Monday, return at 01:55 on Friday.

The cost analysis shows that the most advantageous option when organizing your own transport is the second option, i.e. with 2 drivers. The cost of such transport is PLN 71353.12.

\section{Road, sea and rail transport}

The route was planned on different sections: Opole - Gdańsk: 617 km (rail transport), Gdańsk - Gdańsk Port: 11 km (rail transport), Gdańsk Port - Nynäshamn: (sea transport), Nynäshamn - Stockholm: $58 \mathrm{~km}$ (road transport). Fixed costs as for road and sea transport with the following differences:

- container-tanker rental (www.twsgmbh.de/wynajem-kontenerow-typu- 
cysterna...): 6000 PLN net/month (capacity 26000 gross 24700 net), for loading 220 $\mathrm{m}^{3} 9$ transport sets are needed, - ferry crossing for 1 driver (www.aferry.pl... , www.freightlink.pl...): Gdansk - Nynäshamn EUR 928,75, Nynäshamn - Gdansk EUR 661,49, - railway journey at a rate of up to $620 \mathrm{~km}$ (www.pkpcargo.com/media/100869/...): 5858 PLN (including 30\% of the fee for dangerous goods): additionally, there are correction coefficients:

load capacity over $22 \mathrm{t}$ and length of the container, costs lower than $6.15 \mathrm{~m}$ are 4979.3 PLN (coefficient 0.85 of the price), additionally the ADR fee should be paid: 6473.09 PLN (coefficient 1.3 of price). On the way back from Gdańsk, the costs will amount to PLN 4979.3 (0.5 price coefficient),

- road tolls (www.viatoll.pl...): Opole Olszyna - PLN 60.75, Opole - Gdańsk - PLN 70.99,

- HDS services (www.pkpcargo.com/media/100869/...): $100 \quad \mathrm{PLN} / \mathrm{h}$, loading/unloading the car (www.pkpcargo.com/media/100869/...): 200 PLN,

- loading of goods on the railway in Opole (www.pkpcargo.com/media/100869/...): $400 \quad$ PLN, - cleaning of the tank (www.b10.com.pl/wash-price.html...): 1 set - 440 PLN, 6 sets - 2640 PLN.

Calculation of the cost of the road driven:

- transport by rail: Opole - Gdańsk: 1 set PLN 6473.09, 6 sets - PLN 58257.81, Gdańsk - Opole: 1 set - PLN 2929, 6 sets PLN 26361, - road transport: Gdańsk - Gdańsk Port, Nynäshamn - Stockholm (69 km): 1 set PLN 552, 6 sets - PLN 4968, - sea transport: 1 set - PLN 6885.74, 6 sets PLN

61971.65

Drivers' working hours for 1 driver: departure on Monday at 04:00, return on Thursday at 7:43. The transport time is: $2 \mathrm{~d}$ $19 \mathrm{~h} 43 \mathrm{~min}$. The cost analysis shows that this type of transport is for one set PLN 19299.83, while for 6 sets the cost is PLN
173698.46 .

\section{Transportation commissioned to an external company}

External companies calculate the following transport costs: the rate per kilometre (www.della.pl/price/international...) from Europe to Poland is $3.65 \mathrm{PLN} / \mathrm{km}$, from Poland to Europe - $4.15 \mathrm{PLN} / \mathrm{km}$, average rate: $3.9 \mathrm{PLN} / \mathrm{km}$. The additional charge for dangerous goods is from 15 to $25 \%$. In the case of some transport companies, the rate should be doubled (www.della.pl/price/international...).

Calculated costs for the case under consideration:

- option 1: $1458 \mathrm{~km} \mathrm{-} 1$ driver: 1 set: 17562.48, 6 sets: $105374.9,2$ drivers: 1 set: 17562.48, 6 sets: 105374,9 ,

- option 2: $600 \mathrm{~km} \mathrm{-} 1$ driver: 1 set: 12941,74, 6 sets: $77650.44,2$ drivers: 1 set: 13960.16, 6 sets: 83760,93 ,

- option 3: $1729 \mathrm{~km} \mathrm{-} 1$ driver: 1 set: 20538.04, 6 sets: $123228.2,2$ drivers: 1 set: 20856.84, 6 sets: 125141 .

Summarising the costs for external transport, it can be seen that the lowest rate would have to be paid for Option II if one driver was employed.

\section{Use of decision boards in the transport process}

Decision making boards are algorithmic schemes of information circulation. From this case, the economic and decisionmaking analysis shows which elements are priority and which can be presented in a queue sense (Partyka M., 2001). The decision-making model describes the choice of the type of transport of hazardous materials on the route from Opole to Stockholm. Five decision-making rules have been proposed: 


\section{- Regulation 1:}

If transport is by road and sea route with hired means of transport, the first option concerns Opole - Rostock - Gedser Stockholm.

\section{- Regulation 2:}

If transport is by road and sea route with hired means of transport, the second option concerns Opole - Gdańsk Nynäshamn - Stockholm.

\section{- Regulation 3:}

If transport is by road and sea route with hired means of transport, option three concerns Opole - Frederikshavn Gothenburg - Stockholm.

\section{- Regulation 4:}

If transport is by road, sea and rail, then option four concerns Opole - Gdańsk Gdańsk Port - Nynäshamn - Stockholm.

\section{- Regulation 5:}

If the transport is carried out using an external forwarding company, the choice of the transport process and the determination of the type of transport remains unknown.

\section{Table 2: Decision-making model for transport process selection [own study]}

\begin{tabular}{|c|c|c|c|c|c|c|}
\hline DECISION & & $\mathbf{R 1}$ & R2 & R3 & R4 & $\mathbf{R 5}$ \\
\hline Is land transport an entry point? & W1 & $\mathrm{Y}$ & $\mathrm{Y}$ & $\mathrm{Y}$ & $\mathrm{Y}$ & $\mathrm{Y}$ \\
\hline Is rail transport the entry point? & W2 & $\mathrm{N}$ & $\mathrm{N}$ & $\mathrm{N}$ & $\mathrm{Y}$ & - \\
\hline Is sea transport the entry point? & W3 & $\mathrm{Y}$ & $\mathrm{Y}$ & $\mathrm{Y}$ & $\mathrm{Y}$ & $\bar{Y}$ \\
\hline Is transport by hired means of transport an entry point? & W4 & $\mathrm{Y}$ & $\mathrm{Y}$ & $\mathrm{Y}$ & $\mathrm{N}$ & $\bar{Y}$ \\
\hline Is there one driver? & W5 & $\mathrm{N}$ & $\mathrm{N}$ & $\mathrm{N}$ & $\mathrm{Y}$ & - \\
\hline Is there two drivers at the entrance? & W6 & $\mathrm{Y}$ & $\mathrm{Y}$ & $\mathrm{Y}$ & $\mathrm{N}$ & - \\
\hline Is the entry point for a ferry trip? & W7 & $\mathrm{N}$ & $\mathrm{N}$ & $\mathrm{N}$ & $\mathrm{Y}$ & - \\
\hline Is the ferry crossing an entry point? & W8 & $\mathrm{Y}$ & $\mathrm{Y}$ & Y & $\mathrm{N}$ & $\mathrm{Y}$ \\
\hline Is it a rental of a container? & W9 & $\mathrm{Y}$ & $\mathrm{Y}$ & Y & $\mathrm{Y}$ & $\mathrm{F}$ \\
\hline Is the choice of a forwarding company an entry point? & W10 & $\mathrm{Y}$ & $\mathrm{Y}$ & $\mathrm{Y}$ & $\mathrm{N}$ & $\mathrm{Y}$ \\
\hline Is the transport implementation an entry point? & W11 & $\mathrm{Y}$ & $\mathrm{Y}$ & $\mathrm{Y}$ & $\mathrm{Y}$ & $\mathrm{Y}$ \\
\hline Is it an input to determine the type of transport? & W12 & - & - & - & - & $\mathrm{Y}$ \\
\hline $\begin{array}{l}\text { Is the choice of the type of transport process an input } \\
\text { element? }\end{array}$ & W13 & - & - & - & - & Y \\
\hline Is the car's allocation an entry point? & W14 & $\mathrm{N}$ & $\mathrm{N}$ & $\mathrm{N}$ & $\bar{Y}$ & $\mathrm{Y}$ \\
\hline Is the driver's choice an entry point? & W15 & $\mathrm{N}$ & $\mathrm{Y}$ & $\mathrm{Y}$ & $\mathrm{N}$ & - \\
\hline Is transport from Opole an entry point? & W16 & $\mathrm{Y}$ & $\mathrm{Y}$ & $\mathrm{Y}$ & $\mathrm{Y}$ & $\mathrm{Y}$ \\
\hline Is transport to Rostock an entry point? & W17 & $\mathrm{Y}$ & $\mathrm{N}$ & $\mathrm{N}$ & $\mathrm{N}$ & $\mathrm{Y}$ \\
\hline Is transport from Rostock an entry point? & W18 & $\mathrm{Y}$ & $\mathrm{N}$ & $\mathrm{N}$ & $\mathrm{N}$ & $\mathrm{Y}$ \\
\hline Is transport to Gedser an entry point? & W19 & $\mathrm{Y}$ & $\mathrm{N}$ & $\mathrm{N}$ & $\mathrm{N}$ & $\mathrm{Y}$ \\
\hline Is transport from Gedser an entry point? & W20 & $\mathrm{Y}$ & $\mathrm{N}$ & $\mathrm{N}$ & $\mathrm{N}$ & $\mathrm{Y}$ \\
\hline Is transport to Nynäshamn an entry point? & W21 & $\mathrm{N}$ & $\mathrm{Y}$ & $\mathrm{N}$ & $\mathrm{Y}$ & $\mathrm{Y}$ \\
\hline Is transport from Nynäshamn an entry point? & W22 & $\mathrm{N}$ & $\mathrm{Y}$ & $\mathrm{N}$ & $\mathrm{Y}$ & $\mathrm{Y}$ \\
\hline Is transport from Frederikshavn an entry point? & W23 & $\mathrm{N}$ & $\mathrm{N}$ & $\mathrm{Y}$ & $\mathrm{N}$ & $\mathrm{Y}$ \\
\hline Is transport to Frederikshavn an entry point? & W24 & $\mathrm{N}$ & $\mathrm{N}$ & Y & $\mathrm{N}$ & $\mathrm{Y}$ \\
\hline Is transport to Stockholm an entry point? & W25 & $\mathrm{Y}$ & $\mathrm{Y}$ & $\mathrm{Y}$ & $\mathrm{Y}$ & $\mathrm{Y}$ \\
\hline Is transport to Gdańsk an entry point? & W26 & $\mathrm{N}$ & $\mathrm{Y}$ & $\mathrm{Y}$ & $\mathrm{Y}$ & $\mathrm{Y}$ \\
\hline Is the transport from Gdansk an entry point? & W27 & $\mathrm{Y}$ & $\mathrm{Y}$ & $\mathrm{Y}$ & $\mathrm{Y}$ & $\mathrm{Y}$ \\
\hline
\end{tabular}




\begin{tabular}{|c|c|c|c|c|c|c|}
\hline Is transport to Gdańsk Port an entry point? & W28 & - & - & - & Y & - \\
\hline Is transport from Gdańsk Port the entry point? & W29 & - & - & - & $\mathrm{Y}$ & - \\
\hline Is the entrance element over $1500 \mathrm{~km} ?$ & W30 & $\mathrm{Y}$ & $\mathrm{N}$ & $\mathrm{Y}$ & $\bar{Y}$ & $\bar{Y}$ \\
\hline Is the entrance element over $1100 \mathrm{~km} ?$ & W31 & $\mathrm{Y}$ & $\mathrm{Y}$ & $\mathrm{Y}$ & $\mathrm{Y}$ & $\mathrm{Y}$ \\
\hline Is the entrance element over $1800 \mathrm{~km} ?$ & W32 & $\mathrm{N}$ & $\mathrm{N}$ & $\mathrm{Y}$ & $\mathrm{N}$ & $\mathrm{Y}$ \\
\hline Acceptance of the transport order & & $\mathrm{X}$ & $\mathrm{X}$ & $\mathrm{X}$ & $\mathrm{X}$ & $\mathrm{X}$ \\
\hline Determination of type and size of cargo & & $\mathrm{X}$ & $\mathrm{X}$ & $\mathrm{X}$ & $\mathrm{X}$ & $\mathrm{X}$ \\
\hline Fixing the delivery date & & $\mathrm{X}$ & $\mathrm{X}$ & $\mathrm{X}$ & $\mathrm{X}$ & $\mathrm{X}$ \\
\hline Review of legislation on the carriage of goods in Europe & & & & $\mathrm{X}$ & $\mathrm{X}$ & \\
\hline Determining the type of packaging of goods & & & & & $\mathrm{X}$ & $\mathrm{X}$ \\
\hline Hire of the transport unit & & $\mathrm{X}$ & $\mathrm{X}$ & $\mathrm{X}$ & & \\
\hline Route mapping & & $\mathrm{X}$ & $\mathrm{X}$ & $\mathrm{X}$ & $\mathrm{X}$ & \\
\hline Checking toll rates & & & & & $\mathrm{X}$ & \\
\hline Determination of transport time & & $\mathrm{X}$ & $\mathrm{X}$ & $\mathrm{X}$ & $\mathrm{X}$ & $\mathrm{X}$ \\
\hline Determination of transport cost & & $\mathrm{X}$ & $\mathrm{X}$ & & & $\mathrm{X}$ \\
\hline Direct carriage & & & $\mathrm{X}$ & & & \\
\hline Intermediate carriage & & & & & $\mathrm{X}$ & \\
\hline Broken carriage & & $\mathrm{X}$ & $\mathrm{X}$ & $\mathrm{X}$ & & \\
\hline Own means of transport & & & & & $\mathrm{X}$ & \\
\hline Vehicle rental & & $\mathrm{X}$ & $\mathrm{X}$ & $\mathrm{X}$ & $\mathrm{X}$ & \\
\hline Hiring a new driver & & & $\mathrm{X}$ & & & \\
\hline Driver employed in an undertaking & & & & $\mathrm{X}$ & $\mathrm{X}$ & \\
\hline Fixing the loading date & & $\mathrm{X}$ & $\mathrm{X}$ & $\mathrm{X}$ & $\mathrm{X}$ & $\mathrm{X}$ \\
\hline Preparation of transport documentation & & $\mathrm{X}$ & $\mathrm{X}$ & $\mathrm{X}$ & $\mathrm{X}$ & $\mathrm{X}$ \\
\hline Carriage of goods & & $\mathrm{X}$ & $\mathrm{X}$ & $\mathrm{X}$ & $\mathrm{X}$ & $\mathrm{X}$ \\
\hline
\end{tabular}

The presented structure of the decision board corresponds to the structure of the decision boards. The lines describe the conditions for the transport of dangerous goods and activities related to the transport process. The rules are described in columns $\mathrm{R} 1 \div \mathrm{R} 5$. As a result of the analysis, it was obtained by associating logical values of meeting or not meeting the conditions of required actions for the realization of the transport process. It can be seen that the conditional and action parts of these rules are multi-elemental.

Dariusz Masłowski, Małgorzata Dendera-Gruszka, Ewa Kulińska And Joanna Rut (2020), Journal of Supply Chain and Customer Relationship Management, DOI: 10.5171/2020.981734 


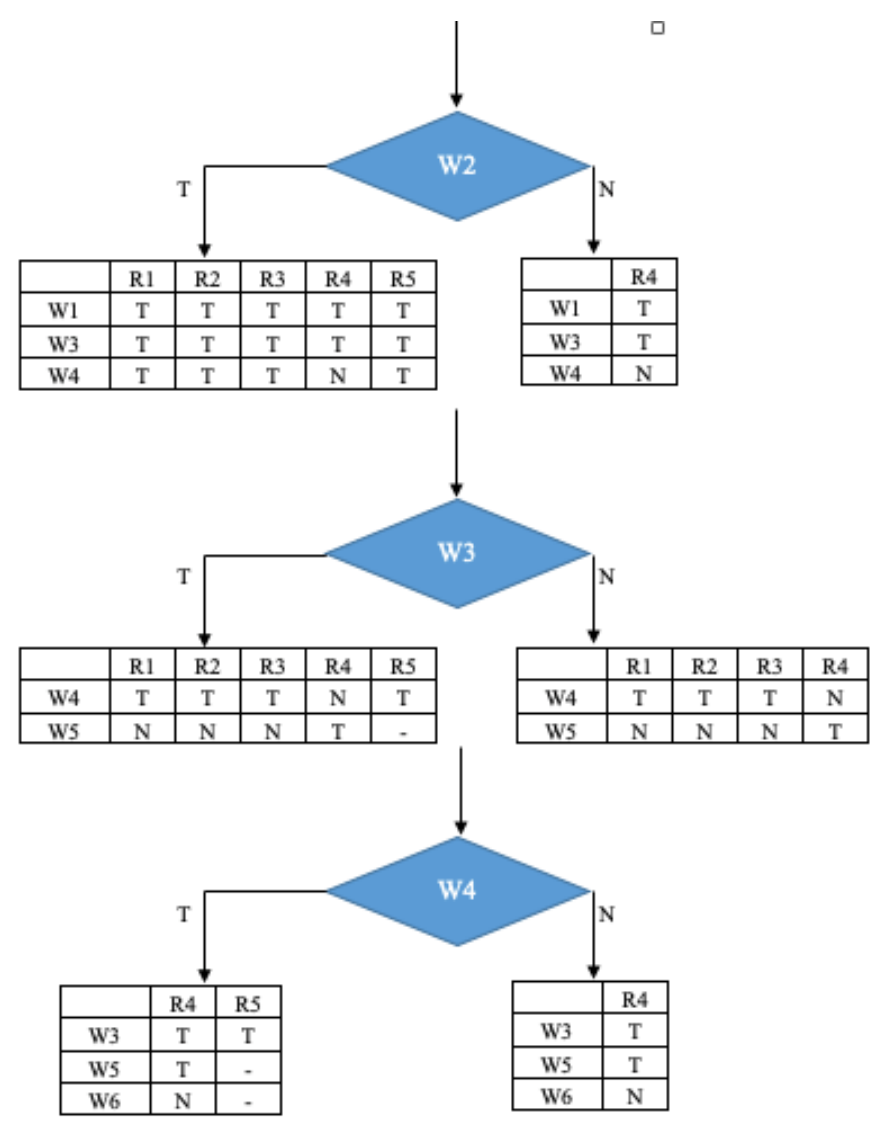

Dariusz Masłowski, Małgorzata Dendera-Gruszka, Ewa Kulińska And Joanna Rut (2020), Journal of Supply Chain and Customer Relationship Management, DOI: 10.5171/2020.981734 


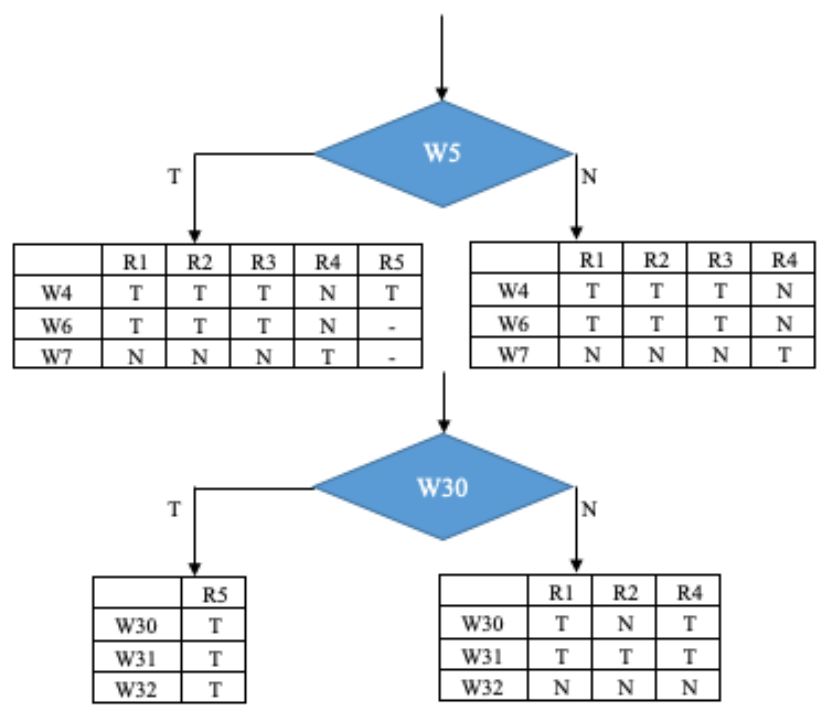

Fig. 2: Example of the endings of the deniers from the decision board [own study]

The presentation of the numerical taxonomy for the decision boards allows the introduction of stages with different levels of detail. The above issue corresponds to the emergence of the socalled partial needs, which are connected with the implementation of the solution to the problem under investigation. The hierarchical approach corresponds to the structure of the process of designing the transport of hazardous materials (Partyka M., 1998, p. 43). Various examples of possible endings of dendrite are presented above. According to the decision analysis, rule 3 was eliminated, while rule 5 is the optimal result of the decision analysis.

\section{Conclusions}

The competition on the forwarding market is very high. Currently, transport companies are obliged to use a range of different methods in order to keep the customer and acquire new ones. The most important factors taken into account when choosing a forwarding company are: punctuality, costs, quality and reliability.

In order to meet customer requirements, forwarding companies must first of all operate quickly, efficiently and, of course, offer attractive prices. The most important determinant of a forwarder's actions is time. The first steps that determine whether the customer chooses a given transport company are the duration of the analysis of the forwarding order. This process must be shortened to a minimum. The decision to choose a forwarding company usually falls on one of the first submitted offers. That is why it is so important to systematize the knowledge of freight forwarders about transport conditions in Europe. The presentation of a generalised transport model is aimed primarily at shortening the time of preparation of a forwarding offer and faster and more efficient execution of subsequent transport procedures.

Each forwarder analyses the given transport model, knows what steps need to be taken for the transport order to come into effect. The analysis of the transport process included in the article also allows to verify and select the most advantageous transport method. The information contained in this article is intended to help people planning international transport of goods to organise transport processes more efficiently. 
The presentation of the numerical taxonomy for the decision boards allows the introduction of stages with different levels of detail. Various examples of possible endings of dendrite are presented in the paper. From the developed model of the decision-making process, it can be concluded that rule 3 (If transport is by road and sea route with hired means of transport) can be eliminated. The optimal result of the decision analysis can be rule 5 (If the transport is carried out using an external forwarding company, the choice of the transport process and the determination of the type of transport remains unknown).

Thanks to the applications contained in the article, both transport companies and manufacturing companies can simply and transparently make a decision on the choice of international freight transport services. The competitiveness of companies in the field of forwarding services makes the choice between own and foreign transport simple enough to make the choice of the price factor directly affect the decision and not the organization of transport by means of own vehicle fleet.

\section{Acknowledgment}

Research financed from the NCN research project no. UMO-2012/05 / B / HS4 / 04139

\section{References}

- Akhmedov, D., Yeryomin, D., Zhaxygulova, D., \& Trepashko, S. (2019). Simulation Model of Transport Traceability System for Transit Customs Goods within the EEU, Transport and Telecommunication Journal, 20(2), 133-141. doi: https://doi.org/10.2478/ttj-20190012

- Ding, L. (2020). Multimodal transport information sharing platform with mixed time window constraints based on big data. J Cloud Comp 9, 11. https://doi.org/10.1186/s13677-0200153-8
- van Heeswijk, W., Mes, M., \& Schutten, M. (2019). Transportation Management. In H. Zijm, M. Klumpp, A. Regattieri, \& S. Heragu (Eds.), Operations, Logistics and Supply Chain Management (pp. 469-491). (Lecture notes in logistics). Springer. https://doi.org/10.1007/978-3-31992447-2_21

- Izdebski M., Jacyna-Gołda I., Jakowlewa I. (2019) Planning International Transport Using the Heuristic Algorithm. In: Sierpiński G. (eds) Integration as Solution for Advanced Smart Urban Transport Systems. TSTP 2018. Advances in Intelligent Systems and Computing, vol 844. Springer, Cham

- $\quad$ Kulińska E., Masłowski D., Wojtynek L. (2018), Improvement of the process of handling participants in road traffic events by the police in the Opole voivodship, Scientific Journal of the Military University of Land Forces, ISSN: 2544-7122, DOI: 10.5604/01.3001.0011.7357.

- Marzec J. (1996), Niektóre teoretyczne problemy spedycji krajowej. ITS, Warszawa.

- Masłowski D., Kulińska E., Kulińska K. (2019), Application of routing methods in city logistics for sustainable road traffic, Transportation Research Procedia 39, pp. 309-319.

- $\quad$ Noureddine M., Ristic M., (2019) Route planning for hazardous materials transportation: multi-criteria decisionmaking approach, Decision Making: Applications in Management and Engineering, Vol. 2, Issue 1, pp. 66-85, ISSN: 2560-6018, eISSN: 2620-0104, DOI:

https://doi.org/10.31181/dmame190 1066n

- Partyka M., (1998), Wybrane zagadnienia logiki i heurystyki w metodologii projektowania - ćwiczenia metodyczne, Oficyna Wydawnicza Politechniki Opolskiej, Opole.

- Partyka M., (2001), Metodologia projektowania - wybrane zagadnienia projektowania technicznego, Oficyna Wydawnicza Politechniki Opolskiej, Opole. 
- Paszek A., Partyka M. (2014), Zastosowanie tablic decyzyjnych w oparacowaniu reprezentacji wiedzy technologicznej, Knosala R. (Ed.), Innowacje $\mathrm{w}$ zarządzaniu i inżynierii produkcji, Tom I, Oficyna Wydawnicza Polskiego Towarzystwa Zarządzania Produkcja, Opole.

- $\mathrm{PN}$ - 72/ M - 78000 Transport. Określenia podstawowe i podział. PKN i M.

- Romanova A., Vygnanov A., Vygnanova M., Sokolova E., Eiduks J. (2019) Problems of the formation of a single transport space on sections of international transport corridors, Procedia Computer Science, Volume 149, Pages 537-541, https://doi.org/10.1016/j.procs.2019. 01.173

- Rydzkowski W., Wojewódzka-Król K. (red.) (2007), Transport. Wydawnictwo Naukowe PWN, Warszawa.

- Stajniak M., Hajdul M., Foltyński M., Krupa A. (2007), Transport i spedycja. Biblioteka Logistyka, Poznań.

- Ustawa z dnia 6 września 2001 r. o transporcie drogowym (Dz.U. $2001 \mathrm{Nr}$ 125 poz. 1371).

- Wojtynek L., Kulińska E., Budzik R., Korczak A. (2016) Przedsiębiorstwa transportowe na rynku usług.
Gospodarka Magazynowa i Logistyka, nr 11.

- $\quad$ www.aferry.pl [access: 9.12.2019 r]

- $\quad$ www.automilan.pl/ [access: 9.12.2019 r]

- www.b10.com.pl/wash-price.html [access: 9.12.2019 r]

- www.della.pl/price/international [access: 9.12.2019 r]

- www.doradca-adr.pl/ [access: 9.12.2019 r]

- www.e-petrol.pl/notowania [access: 9.12.2019 r]

- $\quad$ www.freightlink.pl [access: 9.12.2019 r]

- www.pkpcargo.com/media/100869/ [access: 9.12.2019 r]

- www.postawnaswoim.pl/kariera/ [access: 9.12.2019 r]

- www.pracuj.pl/praca/ [access: 9.12.2019 r]

- $\quad$ www.spectrans.pl/Cennik.html [access: 9.12.2019 r]

- www.tws-gmbh.de/wynajemkontenerow-typu-cysterna [access: 9.12.2019 r]

- www.viatoll.pl [access: 9.12.2019 r]

Dariusz Masłowski, Małgorzata Dendera-Gruszka, Ewa Kulińska And Joanna Rut (2020), Journal of Supply Chain and Customer Relationship Management, DOI: 10.5171/2020.981734 